\section{Malta and the 2019 EP elections - maximising popular engagement with "Europe"}

\author{
Jean Claude Cachia, Fabrizio Ellul, Mark Harwood and \\ Carmen Sammut \\ Institute for European Studies, Department of International Relations, \\ University of Malta, Msida, Malta
}

\section{Malta and the $2019 \mathrm{EP}$ elections}

\begin{abstract}
Purpose - The purpose of this paper is to analyse why Malta continues to show the highest level of turnout for European Parliament (EP) elections in a country where voting is not obligatory. By analysing the Maltese EP elections from 2004 to 2019, the paper seeks to understand why the Maltese engage with a second order election to the degree that they do.

Design/methodology/approach - The paper is a combination of qualitative and quantitative methods, first assessing the context of the 2019 elections, the historical trends and then the factors that help explain why the Maltese continue to engage with EP elections.

Findings - The paper finds that the Maltese political system, highly polarised and dominated by two parties, primarily galvanises people to engage with elections, that it is more about party leadership than actual engagement with Europe and that second order elections in Malta are often run as first order elections.

Originality/value - This paper is the only systematic evaluation of the 2019 EP elections in Malta, discusses categorically that EP elections are rarely about Europe while also showing clearly that political parties can make second-order elections appear as first-order elections should the stakes be high enough.
\end{abstract}

Keywords Malta, Small states, European elections, Second-order elections, Two-party systems, Single transferable voting, Far-right

Paper type Research paper

\section{Introduction}

The fourth European Parliament (EP) elections in Malta, held on May 25, 2019, confirmed the country's post-independence trend for politics to be a two-horse race. The country's two main parties, the Social Democrats, Labour Party (Partit Laburista; PL) and Christian Democrats, the Nationalist Party (Partit Nazzjonalista; PN), won over $92 \%$ of the votes cast and divided the six seats available amongst themselves ( 4 to the PL, 2 to the PN). This result was in-line with the country's status as a stable two-party system, with the two main parties alternating in power since 1950 and all third parties eliminated from parliament in 1966 [1]. Unlike most countries in southern Europe, there was no threat to the stability of this arrangement with other parties only managing 3\% of the vote (Imperium Europa; IE) and

(C) Jean Claude Cachia, Fabrizio Ellul, Mark Harwood and Carmen Sammut. Published in Review of Economics and Political Science. Published by Emerald Publishing Limited. This article is published under the Creative Commons Attribution (CC BY 4.0) licence. Anyone may reproduce, distribute, translate and create derivative works of this article (for both commercial and non-commercial purposes), subject to full attribution to the original publication and authors. The full terms of this licence may be seen at http://creativecommons.org/licences/by/4.0/legalcode 
REPS

5,4

2\% (Democratic Party (Partit Demokratiku; PD), well below the 14\% quota needed to secure a seat.

This article will discuss the factors which help explain the high levels of engagement by the Maltese electorate in EP elections, even though the latter are generally taken as secondorder elections (SOE) and therefore characterised by lower turnout. By analysing the context within which the 2019 EP elections took place, the campaigns as well as post-election analysis, we will discuss three interrelated questions, namely, whether Malta's EP elections are SOE, what Malta's experience can say about the SOE model and what factors help explain why Malta continues to show the highest level of engagement in European elections (from a country where voting is not compulsory)? Additionally, we will also discuss why non-mainstream parties, especially those on the far-right, perform so poorly considering how well they perform in other countries during EP elections.

\section{Second-order elections and Malta European Parliament elections}

Reif and Schmitt (1980) put forward the second-order model the year after the first direct EP election in 1979. The model centres on the assumption that because little is at stake in European elections that this then influences voting behaviour and makes election results differ from first-order elections (FOE). In particular, they noted that because of their perceived lack of importance, voter turnout will be lower than in national elections with more invalid voting (SOE held soon after FOE tend to see electoral fatigue and lower turnout, SOE held towards the end of a FOE cycle tend to see relatively higher turnout). Additionally, the model postulates an impact on party choice and electoral outcomes. In the first case, the SOE are taken as a referendum on ruling parties with a tendency for governing parties to lose votes to other parties. This model applies but with the proviso of how near the SOE is to a FOE. Here the supposition is that should European elections take place soon after national elections, then ruling parties may be protected from losing votes to opposition parties because they still enjoy the "honeymoon" effect of the FOE. Related to this, while FOE voters cast their ballot strategically, in EP elections the fact that the outcome appears to have less direct impact on voters' lives means that people vote less strategically and tend to vote closer to their actual policy preferences, from the heart, with the result that catch-all, mainstream parties tend to do less well.

While the model has withstood the test of time, several studies have sought to refine it, in particular when EP election results have deviated from the model's expectations while some have questioned whether the EP elections are still SOE. Grande and Hutter (2016) and Van der Brug and De Vreese (2016) outline the relevance of the SOE model highlighting how national elections are always expected to be more important for European citizens, with more interests involved, which will result in a stronger political struggle between the main political parties which will contribute to a higher turnout. Van der Brug and De Vreese (2016) believe that even after four decades, the European Elections still do not have a clear purpose. They argue that while the powers of the European Parliament have increased over time, particularly with the Lisbon Treaty, the European Council and European Commission are still the dominant institutions within the EU. This leads them to conclude that while the SOE model has its weakness, it is still relevant for today's European Elections.

In terms of the model itself, Manow (2005) observed that the time variable used by Reif and Schmitt was based on the assumption that governments enact unpopular policies in the first years of office in the hope that these will bear fruit in the period prior to the next election, an assumption that his research indicated could not be confirmed. As indicated by him, and developed further by Schakel (2015), economic performance (economic growth, inflation and unemployment) appear as better indicators of how well ruling parties will 
perform. Schakel (2015) then goes on to discuss how vote switching to other parties is based on party type (Schakel distinguishes between six party types) with a tendency to punish or reward parties [with Reif (1985) observing that the tendency to punish is more noticeable in bipolar party systems]. This latter point reflects the earlier work of Eijk et al. (1996) where it was observed that the tendency to abstain in SOE was not uniform and that fringe parties were less likely to see voter apathy from their supporters than the mainstream parties, even though voting decisions remain largely based on national politics (Hix and Marsh, 2007; Schmitt, 2005; Holbolt and Wittrock, 2011). In addition, Schmitt (2005) observed that much of the SOE literature seemed to apply less to the 2004 accession states, though here the observation centred on the central and eastern European countries and not Cyprus and Malta.

Further to this, an additional discussion has centred on whether the SOE model still applies to European Parliament elections, especially in the light of the increased relevance of the Union in the austerity politics of the Eurozone financial crisis post-2008 as well as the greater prominence of an empowered EP. In particular, Schmitt and Teperoglou (2015) noted that the 2014 elections had the potential for a notable shift in the application of the model, in particular the campaign for the Spitzenkandidaten as well as the increased salience of Europe in domestic politics with growing Euroscepticism (Schmitt and Teperoglou, 2015, p. 288). The latter phenomena is key within the context of whether European elections have become critical elections, namely, indicative of changes in the traditional coalitions between social groups and their political agents, hence necessitating realignment (Key, 1955). While this situation may apply to southern Europe, Malta has always been an anomaly in the region since the economic crisis failed to reach its shores, hence the importance of discussing the context within which the EP election took place.

The application of the SOE model to past EP elections in Malta appears to conform to expectations; since 2004, turnout has always been significantly lower than national elections while the percentage of invalid votes has also been higher (Tables 1 and 2). However, in terms of ruling parties being punished to the benefit of opposing parties as well as smaller,

\begin{tabular}{lcccc}
\hline & 2004 & 2009 & 2014 & 2019 \\
\hline Number of seats & 5 & 5 & 6 & 6 \\
Quota & 40,954 & 41,362 & 35,979 & 37,174 \\
Registered voters & 304,283 & 322,411 & 344,356 & 371,643 \\
Votes cast & $250,691(82.4 \%)$ & $254,039(78.8 \%)$ & $257,588(74.8 \%)$ & $270,022(72.7 \%)$ \\
Valid votes & $245,722(98 \%)$ & $248,169(97.7 \%)$ & $251,851(97.8 \%)$ & $260,212(96.4 \%)$ \\
Invalid votes & $4,969(2 \%)$ & $5,870(2.3 \%)$ & $5,737(2.2 \%)$ & $9,810(3.6 \%)$
\end{tabular}

Source: Compiled from data available at the Malta Electoral Commission (2019)

Malta and the

\section{$2019 \mathrm{EP}$
elections \\ $2019 \mathrm{EP}$
elections}

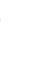

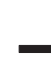


REPS

5,4

308

fringe parties, the picture has been more mixed. While the model applies to Malta in 2004 and 2009 with the opposition PL winning significantly over the ruling PN, the 2014 elections saw the ruling party win a significant majority over the opposition. This can be explained by the honeymoon effect as the PL had only won the national elections 15 months before (Carammia and Pace, 2015, p. 440). In fact, it can be argued that the 2004 EP elections in Malta were the most closely compliant with the SOE model, as non-mainstream parties, in particular the Greens (Alternattiva Demokratika; AD), did significantly well, gaining nearly $10 \%$ of the vote while the ruling party was punished (Harwood, 2005). Since then, the Malta case study tends to diverge in terms of how well the ruling party does vis-a-vis both the opposition and non-mainstream parties. In fact, as Carammia and Pace (2015) note in terms of big parties losing to smaller parties "while we expect this prediction to apply, we also argue that Malta's political institutions significantly limit the magnitude of the effect" (Carammia and Pace, 2015, p. 427).

Several factors can be brought forward to explain this. In particular, the Maltese electoral system limits the possibility of smaller parties from winning seats. While the single transferable voting system allows the electorate to vote for candidates and not parties, it is largely through an inheritance of votes that a candidate is elected. In this way, after ranking candidates (with "1" being the preferred candidate), a quota is established which must be met to win a seat. While a few candidates might exceed the quota (with their surplus votes going to the person listed as second preference on the ballot sheet) the vast majority of candidates are elected though the elimination of those who perform worst. This has two important consequences. The first is that the quota represents a de facto threshold of 14 to $16 \%$ per district (for general elections Malta is divided into 13 districts with five seats available in each district; for EP elections the country is considered a single district with six seats available) and therefore limits the possibility of third parties from being elected and dissuades voters from "wasting" their votes. The second consequence relates to the fact that candidates will only have a chance of inheriting enough votes to meet the quota if they are in a party list with many other "similar" candidates. As very few candidates meet the quota on the first count then candidates must be in a position to inherit from other candidates and only the large parties provide candidate lists with that potential.

However, this electoral advantage is only one element of the political system and the two main parties have, since independence in 1964, consolidated their control over the political landscape. With the absolute control over government given by a two-party state, the ruling party enjoys extensive opportunities for patronage, reinforcing their power, their ability to mobilise support and the importance of first-order elections for the general population. As with the Westminster system upon which it is modelled, Malta is a highly partisan political landscape which merely reinforces the adversarial nature of politics and underscores the high levels of engagement with national elections which enjoy turnouts in excess of $90 \%$.

The power of the parties becomes even more pronounced when we take into consideration the two party's control over the media landscape. Broadly, Maltese media still fits neatly within the "polarized and pluralist" concept presented by Hallin and Mancini (2004), although the islands were not included in their original study (Sammut, 2007). According to Papathanassopoulos (2007), media in southern Europe share common characteristics, such as advocacy reporting, the political instrumentalisation of privately owned media, and the politicisation of public broadcasting and regulatory frameworks, as well as limited autonomy and stalled professionalism.

In Malta, party newspapers initially had strong ideological leanings, but from the 1990s ideologies faded incrementally after the main parties adopted a middle-of-the-road position, and they now hold broadly similar views on several issues, including social welfare, 
education, foreign policy, and economic vision. The party brand has become increasingly blended with the image of party leaders. Disconnected from ideology, electoral support is more dependent on persuasion strategies that are delivered through political communication tactics. In terms of broadcasting, with the introduction of pluralism in broadcasting in 1991, the two main political parties as well as the Catholic church, were given a competitive advantage. They were granted broadcasting licenses before anyone else. The pluralistic scenario had promised to increase the number of commercial players, but few were as successful as the party-owned media. In this way, the Maltese system has been deemed $2019 \mathrm{EP}$ elections idiosyncratic and polarised but within a pluralistic setting it has some saving graces. The two-pronged information stream guarantees that dominant messages emanating from the state and the ruling party are continuously countervailed by strong dissenting ones from the opposition and non-partisan media. While political literature in many parliamentary democracies is now concerned with the weakening of political parties, the Maltese media remain channels of nation-wide debates and citizen participation. Moreover, through their media sub-systems Maltese political parties, trade unions and the Church have remained principal agents of public discourse and key intermediaries between the public and the state. Against this background, the possibility of third parties succeeding, even in SOE, is limited and represents a limitation in the application of the model to a two-party state.

Before analysing the 2019 election, a final word should be said regarding the issue of Europe in domestic politics. While Malta was the only 2004 accession state where a major party (PL) and a significant part of the electorate opposed membership, the question of Europe has been removed from Maltese politics as a divisive issue. Once the Labour party lost the 2003 membership referendum and ensuing general election, the party increasingly came to embrace membership and neither the Social Democrats nor the Christian Democrats have an incentive to politicise membership, a fact that is reflected in the exceptionally high approval rating for the EU amongst the Maltese, always some of the highest in Europe and always above the EU average (Harwood, 2020). The fact that the Maltese economy was barely touched by the financial crisis and continues to boom while immigration [2], a primary concern amongst the Maltese, has not been conflated with EU membership by the main parties, means that Europe was unlikely to be a divisive issue in the $2019 \mathrm{EP}$ elections. To address our original research questions, this paper is centred on a qualitative discussion of the political campaigns with the political parties official manifestos, promotional videos, billboards and social media accounts used to observe their 2019 European Election campaigns. In addition, and to complement the main findings from the qualitative sources, various statistics on Malta's economic performance are also used. Both methods were important to provide a quantitative analysis of the results, and to provide a discussion of the application of the SOE model to the Maltese case study and detailed observations of why some parties fared better than other in the Maltese European elections.

\section{The political context of the 2019 elections}

The European elections took place in a political landscape increasingly dominated by the Social Democrats, the PL. The then Prime Minister (PM) appeared to enjoy significantly high levels of trust amongst the Maltese, but his party had been undermined by increasing concerns regarding the rule of law, especially after revelations regarding the Panama Papers involving one member of the government and the PM's then Chief of Staff and the murder of a prominent journalist (Daphne Caruana Galizia) in 2017 [3]. Increasingly people took to the streets expressing that concern but a principle method used by the Opposition to attack the Government on this issue was through the EP with Nationalist MEPs increasingly pushing for the government's actions to be challenged and the PN spun this as Maltese MEPs 
REPS

5,4

\section{0}

defending the country's reputation; accusations of MEPs tarnishing Malta's reputation would pervade the 2019 campaign.

Much of the PL's support can be attributed to the country's economic fortunes, the economy continuing to expand with Malta having one of the highest growth rates in the EU. However, despite Malta's success a number of concerns started to emerge by the end of 2018 . The top concerns for the Maltese population were Migration (50\%), Housing (29\%), environment/energy and climate issues (28\%) and cost of living/inflation (19\%) (Eurobarometer, 2019), with population growth one of the highest in Europe, in a country already one of the most densely populated places in the world (Eurostat, 2019).

With landslide victories for the Social Democrats in the general elections of 2013 and 2017, the Christian Democrats have been undermined by internal problems, including financial instability and an increasingly divided party on social issues. When the party lost the 2017 elections the leader (Simon Busuttil) resigned and was replaced by a party unknown, Adrian Delia. However, at the time of the 2019 EP elections, the PN appeared more split than ever, split on ideology and split on loyalty with the accusation that the former leader still led a faction within the party which sought to undermine the new leader [4].

Therefore, Malta went into the 2019 elections facing the reality that the PL seemed unassailable, that the PN had not resolved its internal problems, uncertainty reigned as to how the PD would perform when not in alliance with the PN and concern over how successful the far-right would be in garnering votes as xenophobic sentiment continued to grow, primarily online. Economically, the country had never had it so good though it was clear that a lack of regulation prevailed (concerns over standards in the construction industry were not helped by the collapse of a number of buildings in early 2019, culminating in a moratorium on excavations soon after the elections) and racial tensions were mounting, especially after the murder of an African immigrant with the accused being soldiers from the Armed Forces.

\section{The candidates and the electorate}

By the time of the official launch of the campaigns in April 2019, the list of candidates numbered 41, the largest number of candidates to ever contest a Maltese election in a single district. The ruling Labour Party fielded 14 candidates (including two incumbents with one sitting MEP choosing not to run), the Nationalists fielded ten (including all three incumbents) with the Democratic Party fielding four candidates (including one sitting MP). The AD, Alleanza Bidla (AB) and Moviment Patrijotti Maltin (MPM) all fielded two candidates, while the remaining two parties (Brains not Ego and Imperium Europa) fielded a single candidate with the remaining five candidates running as independents, including a member of the Green Party who opted out of his party list mid-campaign.

In addition to the elections being contested by the largest number of candidates ever, it was also of note for the significant increase in those eligible to vote; in addition to the registered Maltese, the election also allowed EU citizens the right to vote. According to the Electoral Commission these amounted to 18,375 voters (TVM, 2019). The 2019 elections were also the first election after the adoption of new electoral laws, passed in March 2018, which lowered the voting age to 16 for national and EP elections (the voting age had been lowered for local council elections in 2015). Malta is now the second EU country (after Austria) to extend the franchise to this age group. In this way, the EP elections have seen a steady increase in eligible voters, as can be seen in Tables 1 and 2, and while the number of votes cast continued to increase, 2019 represented a slight decline in relative turnout compared to 2014. 


\section{The campaigns (and the relevance of "Europe")}

The election campaigns began in earnest in the third and fourth week of April. The Labour Party launched its campaign under the slogan, Malta in our Hearts, much to the annoyance of the PD which had issued its slogan, Our Country in our Hearts, in January. The Nationalists went with Together for our Country, while the AD went with Vote Green, Vote Clean. The slogans underlined a major theme of the elections, variations on the theme of patriotism.

\subsection{The mainstream parties}

The two main parties focused their campaigns on billboards, tv slots and social media. For Labour, a dual campaign was run, focusing on upbeat messages and pledges of future prosperity with focused, negative messages against the opposition, in particular accusing PN MEPs of undermining Malta's position in Brussels and being disloyal [loyalty being a key concept in Maltese society (Mitchell, 2003)]. Particular attention was taken to attack Adrian Delia and former party leader, Simon Busuttil, claiming that the old leader was still calling the shots. The fact that the campaigns were to become highly personal was clear from the first when the Prime Minister (PM) concluded the launch of his party's campaign by stating that "you can call me a socialist [. . . ] a European. But call me Maltese first and foremost" and went on to ask that the electorate compare him with the opposition leader and decide who was best placed to prepare for the future (MaltaToday, 2019a). In fact, only a few candidates would feature in both the PN and PL campaigns with much of the message centring on the party leaders. As with the launch, the PM ended the campaign by making clear that this was an issue of trust and confidence in who could best lead the country with his concluding remark being that "it's either Adrian Delia or me" (MaltaToday, 2019b). For the PN, the campaign was primarily negative, with few proposals given major attention and the focus of the campaign being squarely on attacking the Prime Minister and those around him implicated in the Panama Papers. This negative campaign proceeded to backfire consistently with the party going into the election on a constant back foot.

Outside the general rivalry of the parties and the trading of insults [Malta had the third highest negative campaign of the 28 member states (Novelli and Johansson, 2019, p. 22)] two issues came to dominate the debate with abortion and tax harmonisation becoming a central plank of the Opposition's campaign and launched as a result of the Socialist and Democrats (S\&D) manifesto and Spitzenkandidat. This was of interest because Europe figured in almost no element of the campaign other than those of the smaller parties with the $\mathrm{AD}$ being conspicuous in its positive references to Europe and the IE and MPM in their negative references to Europe (Novelli and Johansson, 2019, p. 186). Hardly any of the EP group manifestoes were referenced, none of their logos used nor focus given to the Spitzenkandidat, with both Manfred Weber (EPP) and Frans Timmermans (S\&D) visiting the islands but only appearing in the context of the PN's campaign on abortion and tax harmonisation.

The topic of abortion was always going to be a sensitive one with the issue entering the Maltese political space in the past two years, especially after the approval of the morningafter pill in 2016, and while all parties, including the Greens, remain committed to the ban on abortion, the issue increasingly rose to prominence, in the light of the S\&D manifesto pledge for "every individual (to have) access to their full sexual and reproductive rights (and) the right to decide over their own body" (S\&D 2019). By May the issue had entered centre stage with Adrian Delia stating, on 12 May, that a vote for Labour was a vote for abortion and that the elections were a referendum on the introduction of abortion in Malta. Billboards were erected of a newborn baby with the slogan "Life: it is my right". However, the PN was soon 
REPS

5,4

312

on the back foot once again and having to defend its campaign, stating that it was duty bound to let the electorate know that both the S\&D and Greens were in favour of abortion rights even though the Labour Party had reiterated its stand against abortion. One of the most important consequences of the debate was the exit of Arnold Cassola from the Greens as the latter refused to disassociate itself from the comments of one of its candidates that there should be a safe space in which to debate abortion. With his shock exit, the AD lost its last founding member and its most prominent public face. More seriously, "the PN's quixotic campaign on abortion wasted what little energy and desire existed for a positive, prepositional campaign" (Pace and Carammia, 2019, p. 200).

The other major theme that came to dominate the PN's campaign was concerns over tax harmonisation following the S\&D's pledge to "stop downward corporate tax competition" (S\&D 2019) and Frans Timmermans commitment to the same. Repeated reference was made throughout the closing week of the campaign to the issue with the major parties trading accusations that the country's reputation was under threat. In this way, while Europe did not feature in a prominent light, it was used as a reactive element in the PN campaign though neither issue gained much traction, and this could be for several reasons, including the fact that no party was advocating in favour of abortion while corporate tax harmonisation, a valid concern, might have been difficult to sell to the general public. Ultimately, beyond the mud-slinging and accusations of disloyalty to Malta, the issue of trust seemed to dominate; trust to defend Malta's interests and trust to defend the Maltese Government. In a survey published on 12th May, the biggest factor cited for supporting candidates was their ability to "defend Malta"s name'; for PL voters this was a key issue $(36 \%)$ but less so for PN supporters (14\%) (MaltaToday, 2019c). For PL supporters, the second important issue was "showing support for government" followed by illegal immigration. For the PN it was, secondly, "capable MEPs" and then the environment and combatting environmental destruction (MaltaToday, 2019c).

Beyond the two main parties, the AD and the PD ran less conspicuous campaigns though PD candidates were of note for their innovative use of social media, the candidate Camilla Applegren being especially active online. For the $\mathrm{AD}$, it decided to focus its energy on the Local Council elections, which were held simultaneously with the EP elections. In fact, AD's manifesto "Green is the answer" combined both the European and Local Elections; the logo designed for this campaign were abstract geometric shapes (AD, 2019). The end result was a lacklustre campaign and AD's worst electoral result in its 30-year history. For the PD, most of the campaign was based on national issues with the party highlighting the lack of good governance in Malta and the damage the Labour administration was doing to the environment. The campaign was critical of both the Labour and Nationalist Parties, yet it was not just focused on the criticism towards them, since it also highlighted the work the party would do for the sake of the country. One of the main weaknesses of the actual campaign was that no political manifesto was published by the party. In addition, and as in the case of all the parties, the symbol of the ALDE group was rarely present on promotional material.

\subsection{The non-Mainstream parties}

Norman Lowell, IE's founding member, was IE's only candidate for the 2019 EP elections. His image featured in leaflets, posters and public information video clips, his eccentricity making him a celebrity of sorts. Often invited onto small cable TV channels and programmes to court controversy, this was amplified by a "shocked" mainstream media creating intentionally or unintentionally a media cycle of discussion around him, even though the main Maltese TV stations refused to give Norman Lowell air space. Stylistically 
IE campaign was rather basic and rudimentary. The low budget campaign was still diverse in its public information tools using print, video and social media in the same manner of the more funded bigger parties. IE campaign also ventured into themes of "democracy", "corruption", "patriotism" and "environment". Typically, heavy on migration, this shift can be seen as a strategy to tap into different public concerns and diversify its political base. IE has steadily increased its voting base in the European Elections, from $0.6 \%$ in 2004 to $3.2 \%$ in the 2019 EP Elections surpassing the two smaller mainstream parties (AD and PD) to become Malta's third party. Beyond the party, Norman Lowell's focus on the anti-immigrant voters led to a split in the anti-immigrant vote between IE and the upstart party, the Maltese Patriots (MPM).

In terms of the latter, MPM centred their message around a nostalgic past when Malta stood better with less foreigners with the party running under the slogan "fair, safe and Christian Europe" with the party leader, Henry Battistino, announcing that it was about making "Malta for the Maltese" (Moviment Patrijotti Maltin, 2019). The MPM EP campaign often featured images of former Prime Ministers Dom Mintoff (Labour Party) and George Borg Olivier (Nationalist Party) as an attempt to connect with a golden generation and bridge Malta's two-party system. It seems that MPMs objection to foreigners tended to be a la carte - seeing some abstract concept of foreign groups (mainly, but not only, African nationals coming by boat) as a threat to Malta's culture and security while other foreign nationals were depicted as friendly allies. This inconsistency might have also contributed to their poor results. By the end of the campaign, the party's principal pledge was to stop any attempt to introduce abortion in Malta as well as the need to combat an excessive population and restrict entry, even from Europe. It is interesting to note that the biggest number of "angry" posts came from MPM, which may be described as the most Eurosceptic party in Malta. It must be noted that members of this small party did not merely post original campaign material but, to reinforce their message, they also selectively shared international news that portrayed "foreigners" (namely people of colour and Muslims) in a negative light. MPM drove a negative appeal and numerically they had a wider variety of posts than the stronger opposition party PN, but the end result for MPM was an electoral disaster of registering just 771 votes or $0.3 \%$.

\subsection{Online media}

As seen above, an interesting element in the 2019 campaign was the use of social media. While the main parties have their own media outlets, social media represented a levelling of sorts, allowing the non-mainstream parties to deliver their message. That said, the amounts spent by candidates often went into the tens of thousands of euros and the main parties maintained their grip of the media landscape due to their ability to spend more on online campaigns. In fact, Malta saw the highest number of adverts per head (from across the EU) and the main parties spent significantly to get their message across on Facebook, Instagram and Twitter:

in total over the month of May, Maltese political Facebook advertisements totalled 4,552, with a matching expenditure of €116,959. While far larger countries such as Germany had far more political advertisements [...] in per capita terms, Malta had 10 times as many advertisements (Malta Independent, 2019)

Before analysing the results, mention must be given to a final factor that may have influenced the actual result, namely, the targeting of the non-Maltese vote. The PL appears to have become acutely aware of the importance of this segment of the electorate as the campaign progressed and increasingly started issuing posters in both English and Maltese, something the PN failed to do. More tellingly, the PL sent letters to foreign residents 
REPS

5,4

\section{4}

Table 3.

EP Election

percentage results for parties running in the 2019 Malta elections outlining why they should vote PL. It is a dubious tactic and facilitated by the government's access to government databases, but it is one that both parties have used in the past. By targeting the foreign vote, the $\mathrm{PL}$ was conspicuous in this regard, the $\mathrm{AD}$ being the only other party which was aware of the importance of delivering their message in both national languages.

\section{The results and the transfer of votes}

The final results can be seen in Table 3. As with every EP election, the Labour party won a resounding victory while the PN saw its vote decline. From the Labour party, both incumbents were elected, with Miriam Dalli securing nearly double the quota and Alfred Sant being elected on the second count. The third and fourth most successful Labour candidates on the first count, Alex Saliba and Josianne Cutajar, also went on to be elected (on the 39th count) with Labour winning four of the six seats. For the Nationalists, one incumbent was elected immediately, Roberta Metsola, while another incumbent, David Casa, was elected on the 38th count with the final incumbent losing his seat.

Of the other parties, the Greens saw a decline in support; while their vote fell significantly, the decision of its leading candidate, Arnold Cassola, to run as an independent mid-campaign, split the party's vote and had he remained on the party ballot the AD's final tally would have been $1.5 \%$, though this would still have represented a significant drop from the 2014 EP elections. Conversely, support for the anti-EU party (AB) increased as well as support for IE. The 8,238 votes for Norman Lowell in 2019 seem to confirm the second order nature of these elections because his only foray into first order elections, the 2008 general election, saw him win only 88 votes on two districts. The Democratic Party (PD) managed to increase its votes over the last general election by $10 \%$, no mean feat considering the fact that it was not running in alliance with the PN. That said, much of the PD's tally came from a single candidate, Camilla Applegren, with the party leader, Godfrey Farrugia, winning roughly the same number of votes as he had in the general election. Without Appelgren, the party's performance would have been drastically poorer than in 2017. Considering the fact that many of her votes were not transferable or went to a PN candidate (see below), while many of the other PD voters did not transfer their votes to her would seem to imply that she caught a part of the electorate which might not have identified as PD in the 2017 elections and so might not vote PD again (as the only non-Maltese candidate on the ballot she might also have garnered much support from the 18,000 nonMaltese voters who will not be part of the next FOE). Table 3 also indicates that independent candidates (IC) only gained $1 \%$ of the votes.

One of the most interesting elements of the STV system is that it allows you to map the preferences of voters due to the fact that the electorate can, in theory, vote for everyone on the ballot sheet. The process of inheriting votes is therefore an interesting window into the diversity of political opinion of the individual voter. Of special note in this regard was those

\begin{tabular}{lllccccccc}
\hline & PL & PN & PD & AB & AD & BNE & IE & MPM & IC \\
\hline 2019 & 54.3 & 37.9 & 2 & 0.5 & 0.7 & 0.1 & 3.2 & 0.3 & 1 \\
2014 & 53.4 & 40 & - & 0.4 & 2.9 & - & 2.7 & - & \\
2009 & 54.8 & 40.5 & - & - & 2.3 & - & 1.5 & - & 1.5 \\
2004 & 48.4 & 39.8 & - & - & 9.3 & - & 0.7 & - &
\end{tabular}

Source: Data compiled from the Malta Electoral Commission (2019) 
that voted for Normal Lowell (IE) who eventually gained over 9,000 votes. Of those, over $63 \%$ were non-transferable, meaning that over 6,000 people voted for him only. Of those votes which were transferred, a little more than half went to Labour and just under $50 \%$ went to the Nationalists, in both cases, to male candidates. The same can be said for the MPM where a majority of the second preference votes went to Normal Lowell or were not transferable with the remaining 15\% going to the PN and PL equally. More interestingly, Lowell had inherited votes from PL and PN voters as well as PD and, surprisingly, AD (an interesting anomaly considering that the Greens and the far-right are not automatic bedfellows). A similar picture was to be found with Camilla Applegren who had 51\% of her votes non-transferable, while the majority of those inherited went to the PN and David Casa in particular. Also of note, most of the votes of the other PD candidates went to the PN and not to Appelgren (MaltaToday, 2019d) [5]. It would seem that SOE do enable people to vote "from the heart", and this might explain the sometimes-arbitrary sequence of voting on some ballots.

\section{Discussion: analysing the result}

Following the discussion provided in our literature review and basing ourselves on the summary of testing the aggregate hypotheses of the SOE model provided by Schmitt and Teperoglou (2015, p. 295), we can see to what degree the 2019 elections in Malta conform to the SOE model (Table 4).

As can be seen in the table, there are many elements which continue to indicate that the Maltese EP elections are a SOE. Foremost amongst these are the fact that, with turnout continuing to decline, it was significantly lower than turnout for national elections which are always above $90 \%$. Invalid votes were also much higher than in FOE, while some smaller parties tended to perform better than in national elections; $\mathrm{AB}$ saw an increase while the PD also saw an increase (IE cannot be assessed due to the fact that they have not contested the general election in recent years). In this regard, we can state that smaller parties did well relative to the catch-all parties though not to any significant degree other than in the case of the IE. However, while most parties performed less well than in national elections due to the lower turnout, the performance of parties relative to each other tends to undermine the application of the model to Malta. While the model should predict a lower level of support

\begin{tabular}{ll}
\hline SOE aggregate hypotheses & Malta 2019 EP elections \\
\hline 1. Lower turnout compared with previous FOE & Yes $(19.4 \%)$ \\
2. Higher blank/invalid votes compared with previous FOE & Yes $(3.6 \%)$ \\
3. Government party losses compared with previous FOE & Yes \\
3.1 Government party losses related to the electoral cycle & Mid-term \\
4. Opposition party wins & No \\
4.1 Opposition big parties losses compared with previous FOE & Yes \\
4.2 Total losses for big parties & Yes \\
5. Small parties gain & Yes \\
5.1 Anti-EU parties and extreme-right parties better performance & Yes \\
5.2 Emergence of new parties that gain seats in the EP & No \\
Electoral cycle & Mid-term \\
Previous FOE & 3 June 2017 \\
Concurrent election with EP & Local Council
\end{tabular}

Source: Authors own based on data gathered from the Malta Electoral Commission (2019)

Table 4.

Summary of testing the aggregate hypotheses of the SOE model in the 2019 EP elections in Malta 


\section{REPS}

5,4

\section{6}

Figure 1.

Comparison of Maltese Economic Statistics 2004-2018 for the ruling party as well as greater support for the opposition, the Malta case study fails to meet this expectation. Carammia and Pace (2015) explain this phenomena (which had surfaced in 2014) as being linked to the long-term electoral cycle of the country and the fact that the ruling PL, in 2014, was still enjoying a honeymoon of sorts after only 15 months in government. However, if we apply the hypothesis put forward by Manow (2005) and Schakel (2015), the economy should be a clearer indicator of how votes will be spread. In applying this to Malta, it is interesting to note that generalisations are difficult with a singlecase study and only (effectively) three elections to compare, but some correlation appears to exist (Figure 1). In fact, beyond the novelty of the 2004 elections as the first EP elections in Malta, the year 2009 saw a significant decline in GDP growth and a small rise in unemployment during the same year that the ruling party (the $\mathrm{PN}$ ) lost significantly with a punishment vote that saw the PL win a large majority. After 2013, with Labour now in power, we see economic indicators remaining relatively stable (beyond the 2014 and 2015 GDP growth peaks) with strong GDP growth, a consistent decline in unemployment and low inflation. These indicators run through both the 2014 and 2019 elections where the ruling party won the majority of the vote. In this way, the Malta case study, after a superficial discussion of the statistics, appears to indicate that economic performance seems to be a more precise indicator of how SOE actually work, as opposed to the time variable in Reif and Schmitt's (1980) original model.

Where Schakel's discussion of SOE elections is less clear within the Malta context is in terms of the tendency to reward or punish non-mainstream parties. As observed in the previous discussion, there is a greater tendency for bipolar party systems to see "punishment" voting, while multiparty systems see more varied vote switching with Schakel (2015) distinguishing between six types of parties. However, this model depends primarily on evaluating ruling parties who are not delivering economic prosperity with the degree to which the economy is deteriorating indicating the degree to which voters will want to punish established parties and reward new parties. As discussed above, it is difficult to discuss this scenario in terms of the Malta case study as the economy has continued to grow consistently since membership (beyond the 2009 contraction which was a consequence of the 2008 financial crisis). While the IE performed relatively well and could indicate the only

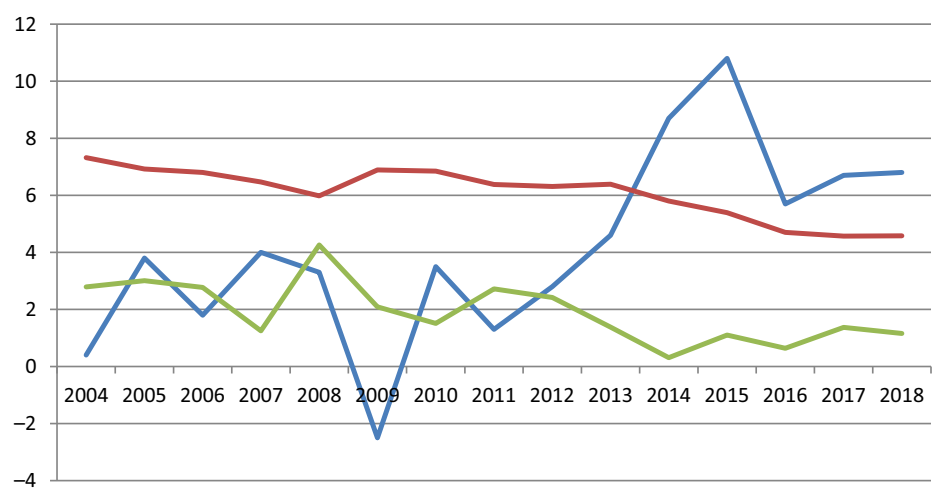

Source: Authors own based on data gathered from the National Statistics Office (2020) 
option for Eurosceptic sentiment to be expressed in a party system where all main parties are in favour of European integration, it is clear that Maltese voters still find it difficult to switch allegiance to non-mainstream parties, meaning that Schakel's (2015) observations are difficult to discuss in the Malta context.

Several factors can be brought forward to explain this situation, both structural and political in nature. In the first place, structurally, the significant threshold needed to win a seat means that there is no real opportunity for third parties to win. As most of Maltese politics is highly polarised, people will often vote so as to ensure that the "other" party does not secure a victory. Voting for third parties can, therefore, be a means of registering unhappiness with the mainstream parties but will be an unattractive option because most people wish to vote strategically so as to ensure that the "other" party does not perform well and this can only be achieved by voting for one of the two main parties, due to the STV "threshold". Further, it can be argued that the PL's success in undermining the original SOE model and outperforming the opposition was also a consequence of two political factors. The first is the PL's ability to fight an effective campaign which balanced a progressive, upbeat agenda with targeted attacks on the opposition. This allowed it to depict itself as the only party competent to run the country (and it was in this language that the campaign was framed). Also, related to this is the fact that the election was actually fought as a FOE, as an extension of the PM's ambitions to secure an EU post. The then Maltese Prime Minister, Joseph Muscat, was still relatively young and had declared, soon after winning the last general election, that he would not run a third time, while also making it clear that he had ambitions to work again in Brussels (he is a former MEP). This expectation was seen in a frenzied series of reports, throughout July, where his team made public that he was on the shortlist of people being discussed for high office within the EU (the expectation was that he would seek the Presidency of the European Council). This adds a further dimension to the fact that the PL campaign was often more about the PM than the actual candidates.

For the PL, its greatest ally was the opposition itself, the second factor. The party has struggled since 2013 to regain its footing, both in terms of party financing, ideology and party cohesion. The party has become so riven by internal dissent that the immediate fallout from the election was an unedifying washing of party laundry in the media as a sitting MP, David Stellini, resigned his seat in Parliament after he failed to win an EP seat, stating that he could not survive on an MP's wage. The by-election to fill his seat became an unpleasant spectacle and showed the deep structural problems within the party. With an opposition which failed to instil confidence and which ran a very lack lustre campaign and with a twoparty system that corrals the electorate into voting for only two parties (with a failure to vote being perceived as a vote for the opposing party and therefore a manifestation of disloyalty), the outcome confirmed the limitation of the SOE model in this regard. Much of the lowest turnout was registered in the 9th to 12th districts, areas normally associated with the PN vote. It would seem, when disillusioned, traditionally $\mathrm{PN}$ voters merely stayed home and did not feel the need to switch their vote.

\subsection{Engaging with European Parliament elections but not with Europe}

In analysing the $2019 \mathrm{EP}$ elections in Malta, it is clear that the high levels of engagement are a manifestation of the Maltese political system and not reflective of efforts, at an EU level, to galvanise the European electorate to engage with these elections. The main parties use these elections as an extension of the bipartisan rivalry that shapes daily politics. Turnout is significantly higher than in other states because the Maltese are heavily engaged in politics; a two-party system ensures that political change involves significant shifts in formal and informal policy-making networks and impacts opportunities for patronage, which is a 
REPS

5,4

318

primary currency of the Maltese political system. With extensive media interests, the main parties are able to shape the discourse and determine the political and media agenda and galvanise support for, and engagement with, elections. The Maltese are reminded that these elections matter and that people are expected to show support for "their" party.

The absence of Europe in the campaigns was especially clear in terms of the mainstream parties. The EP political groups to which the PL and PN belong did not feature in the campaigns, not in terms of their manifestoes, their logos or their Spitzenkandidaten. Where they did feature, as an extension of the PN's attempts to politicise S\&D commitments regarding tax harmonisation and women's health, they were soundly depoliticised and the only resultant message was that "Europe" had a negative potential to undermine Maltese values and interests. Of greater note was the fact that the use of "Europe" or EP political group manifestoes was more prevalent amongst the other parties where their popular support was low. In this regard, $\mathrm{AD}$ and $\mathrm{PD}$ were both conspicuous in their reference to the European Greens and ALDE and yet neither party performed well while the far-right, antiEU parties used a generic image of Europe as representing a threat to Maltese values but with no actual link to EP groups or specific EU imagery. Here, the anti-immigrant image was prevalent and appears to have won support, primarily for Imperium Europa.

Ultimately, the EP political groups and the Spitzenkandidaten did not feature in Malta's EP elections and cannot be considered a factor in explaining the high levels of engagement. Of course, "Europe" is no longer a divisive issue in Maltese politics and the country's economic success during the global recession meant that there is little potential to politicise membership so domestic politics, and by extension the 2019 EP elections, were unlikely to have been about European issues or European politics and their impact on Malta. As with many EU countries, the EP elections are an extension of national politics and domestic political issues, as discussed earlier (Hix and Marsh, 2007; Schmitt, 2005; Holbolt and Wittrock, 2011) and while "Europe" has featured more strongly in the domestic politics of EU Mediterranean states (as austerity measures dominated domestic politics from 2009 onwards), this has not been the case in Malta where economic performance ensured Euroscepticism remained low.

\subsection{Far-Right parties in Malta}

The Far-Right parties in Malta obtained 3.5\% of the total votes allocated to IE $(3.2 \%)$ and MPM $(0.3 \%)$ which was far below similar results obtained by other Far-Right parties in other EU MS. In this way, while IE followed a certain EU trend for votes going to populist and far-right parties, its relative low vote count must be understood within Malta's particular political context. While the failure of third parties to make any particular inroads has been explained above, additional factors need further elaboration, including the lack of infrastructure and long-term strategy of the smaller parties, which leads to lack of funding for campaigns, human resources to run the day-to-day administration of a party and professionals in the field of policy, communication and politics as well as struggling to field enough candidates.

Furthermore, Malta's political campaign is heavily reliant on the parties' canvassers typically the local councillors and party delegates. The parties' foot soldiers are generally well connected with the community and are the ones that introduce the party's aspiring politician to the voter. A certain network of trust and access to power is thus created. Both the PL and PN are heavily rooted in different localities, dominating the local council elections (with very few exceptions) but smaller parties do not have such foothold and obviously they struggle with elections. 
Further, Malta's political system remains highly pragmatic with both main parties shifting ideology through the years, retaining certain flexibility within its ranks. Their ability to change position makes them also highly unlikely to implode as can be typical in other EU MS. Their instinct for political survival is remarkable. The 2019 Eurobarometer survey highlighted how trust in the government was at $63 \%$ compared to the EU average of $35 \%$. In addition, while trust in Malta's political parties stood at 36\%, it was still double the EU average of $18 \%$. This means that the electorate did not feel the need to shift their support towards other parties and reflects this pragmatic and flexible party system.

On top of this, the general content quality of the Far-Right party campaigning was particularly poor. IE is dependent on Norman Lowell - who has been on and off the political scene since 2004 - an eccentric individual that courts entertaining controversy. It is difficult to see how IE and the Far-Right could have garnered more support based on their EP Elections campaign when a European Commission survey in 2019 revealed that Maltese citizens use television stations (63\%), websites (43\%), social media (36\%) and radio $(31 \%)$ to gather information on the European Union (Eurobarometer, 2019). These far-right political parties are still not able to compete with the established political parties due to the fact that the latter have their own radio and television channels.

\section{Conclusion}

In conclusion, we can say that the Maltese EP elections confirm many of the observations predicted by the SOE model but that there are important limitations, primarily centred on the fact that the STV system coupled with the strong, adversarial nature of Maltese politics and dominance of the two main parties means that there are few incentives to vote for nonmainstream parties and that, in this respect, the dynamic expected in terms of support for ruling and non-ruling parties will be skewed, especially when opposition parties make it difficult for the electorate to vote for them. With no incentives to vote for third parties and negligible expectations of that support being effective, voters tend to be corralled into betting on a two-horse race. The 2019 elections saw a notable win for the PL, winning four of the six seats available, and while some smaller parties did perform better under the SOE, the stability of the two-party system in Malta remains and appears to extend from FOE to SOE elections, reinforcing the perception of the parties' unassailable dominance of postindependence Maltese politics and society That said, while the Far-Right did not obtain a relative high amount of votes, their toxic rhetoric (often anti-immigrant) tends to be "adopted" by the Opposition party of the day who see "populist" rhetoric as a way to tap into certain concerns, indicating a potential for fringe politics to infiltrate the mainstream.

However, the Malta case also confirms the observation of Manow (2005) and Schakel (2015) that the time variable of the original SOE model is not a precise predicator of how mainstream parties perform and that a more reliable indicator is economic performance. With this refinement of the original model, the results seen in Malta, which can appear anomalous, appear to conform to the model more precisely and while certain structural realities of the Maltese political system limit the extension of the discussion to the punishment/reward dynamic expressed by Schakel (2015), it does indicate that the SOE model is more applicable when economic performance replace time as the variable.

In addition to these general observations about SOE elections in Malta, EP elections in Malta show high levels of engagement because they are seen as an extension of domestic politics. With the major parties allocating resources as though fighting a first order election and party loyalty being an integral part of a two-party political system, the Maltese are made to feel that these elections matter. However, the context in which they are fought is a domestic one and Europe does not feature prominently and where it does, as with the non- 
REPS

5,4

mainstream parties, engagement is minimal. While the EP and its political groups have tried to deliver the message that "Europe" matters and that EP elections are critical, the Maltese case study indicates that it is rarely about Europe and always about national politics.

\section{Notes}

1. In the 2017 general election, a third party entered parliament, the Democratic Party (Partit Demokratiku; PD), but as part of an electoral coalition with the Christian Democrats.

2. The concern on immigration has typically been on the number of irregular disembarkation that Malta experienced from Libya since 2002, amounting to over 25,000 individuals (mainly from sub-Saharan countries) being rescued and brought to Malta. For the past few years, Malta has also experienced an increase of EU and non-EU nationals attracted by Malta's economic growth and low unemployment rates, which also added to the political discourse on migration.

3. These issues were the basis of popular dissent towards the end of 2019 which forced the Prime Minister, Dr Joseph Muscat, to announce his resignation which became effective from January 2020. He was replaced as party leader and Prime Minister by Dr Robert Abela.

4. Simon Busuttil resigned his seat in Malta's Parliament in January 2020 to become Secretary General of the European People's Party within the European Parliament.

5. Appelgren was of note for pushing a strong green agenda and for endorsing abortion in the closing days of the election, leading to a fracture between her and the party.

\section{References}

Carammia, M. and Pace, R. (2015), "The anatomy of a misfit: the 2014 European election in Malta", South European Society and Politics, Vol. 20 No. 3, pp. 425-444.

Eijk, C., Franklin, M. and Marsh, M. (1996), Choosing Europe? The European Electorate and National Politics in the Face of the Union, MI University Press, USA.

Eurobarometer (2019), "National report on public opinion in Malta”, available at: https://ec.europa.eu/ malta/sites/malta/files/eb90_final_en.pdf

Eurostat (2019), “EU population up to over 513 million on 1 January 2019', news release, no. 114/2019 10 July 2019", available at: https:/ec.europa.eu/eurostat/documents/2995521/9967985/310072019-BP-EN.pdf/e152399b-cb9e-4a42-a155-c5de6dfe25d1

Grande, E. and Hutter, S. (2016), "Introduction: European integration and the challenge of politicisation”, in, Hutter, K., Grande, E. and Kriesi, H. (Eds), Politicising Europe: Integration and Mass Politics, Cambridge University Press, Cambridge, pp. 3-31.

Hallin, D. and Mancini, P. (2004), Comparing Media Systems, Cambridge University Press.

Harwood, M. (2005), "Malta", in Lodge, J. (ed.), The 2004 Elections to the European Parliament, Palgrave.

Harwood, M. (2020), "From Euroscepticism to euro-enthusiasm: how Malta weathered the Eurozone crisis", South European Society and Politics, doi: 10.1080/13608746.2020.1746542.

Hix, S. and Marsh, M. (2007), "Punishment or protest? Understanding European parliament elections", The Journal of Politics, Vol. 69 No. 2, pp. 495-510.

Holbolt, S. and Wittrock, J. (2011), “The second-order election model revisited: an experimental test of vote choices in European parliament elections", Electoral Studies, Vol. 30 No. 1, pp. 29-40.

Key, V. (1955), “A theory of critical elections”, The Journal of Politics, Vol. 17 No. 1, pp. 3-155.

Malta Electoral Commission (2019), "Election results", available at: https://electoral.gov.mt 
Malta Independent (2019), "EP elections: how Malta eclipsed every other country in social media political advertising", available at: www.independent.com.mt/articles/2019-06-30/local-news/EP-electionsHow-Malta-eclipsed-every-other-country-in-social-media-political-advertising-6736210199

MaltaToday (2019a), "Joseph Muscat puts spotlight on the environment at the start of electoral campaign", available at:www.maltatoday.com.mt/news/national/94618/watch_joseph_muscat_puts_spotlight_ on_the_environment_at_the_start_of_electoral_campaign\#.XTcBAq2B2i4

MaltaToday (2019b), "Joseph Muscat closes election campaign in Birgu: 'It's Adrian Delia or me”, available at: www.maltatoday.com.mt/news/europe-2019/95218/joseph_muscat_closes_election_campaign_in_ birgu_its_adrian_delia_or_me\#.XTcEWq2B2i4

MaltaToday (2019c), "MEPs who 'defend Malta's name' is the most important election issue", available at: www.maltatoday.com.mt/news/europe-2019/94918/maltatoday_survey_meps_who_defend_maltas_ name_is_the_most_important_election_issue\#.XTcLKq2B2i4

MaltaToday (2019d), “Angry votes? 64\% of Norman Lowell's votes were non-transferable”, available at: www.maltatoday.com.mt/news/europe-2019/95316/angry_votes_64_of_norman_lowells_votes_we re_nontransferable\#.XTcSVq2B2i4

Manow, P. (2005), "National vote intention and European voting behavior, 1979-2004: Second order election effects, election timing, government approval and the Europeanization of European elections", MPIfG Discussion Paper, Paper 05/11, available at: www.mpifg.de/pu/mpifg_dp/dp05-11.pdf

Mitchell, J. (2003), Ambivalent European: Ritual, Memory and Public Sphere in Malta, Routledge.

Moviment Patrijotti Maltin (2019), "Manfiest MEP's 2019”, available at:www.patrijottimaltin.org/ manifest-meps-2019/

National Statistics Office (2020) “Annual reports”, available at: https://nso.gov.mt/en/nso/About_NSO/ Pages/Annual-Reports.aspx

Novelli, E. and Johansson, B. (Eds.) (2019), 2019 European Elections Campaign: Images, Topics, Media in the 28 Member States, Directorate-General for Communication, European Parliament.

Pace, R. and Carammia, M. (2019), 'Malta: Unstoppable Labour?, in De, S. (Ed.), Franklin and Russo (2019).

Papathanassopoulos, S. (2007), "The Mediterranean/polarized pluralist media model countries: Introduction", in Terzis, G. (Ed.), European Media Governance: National and Regional Dimension, Intellect.

Reif, K. and Schmitt, H. (1980), "Nine second-order national elections - a conceptual framework for the analysis of European election results", European Journal of Political Research, Vol. 8 No. 1, pp. 3-44.

Reif, K. (ed.) (1985), Ten European Elections, Aldershot.

S\&D (2019), "A new social contract for Europe: PES manifesto 2019", available at:www.pes.eu/ export/sites/default/.galleries/Documents-gallery/PES-Manifesto-2019_EN.pdf_2063069299.pdf

Sammut, C. (2007), Media and Maltese Society, Lexington Press.

Schakel, A. (2015), "How to analyse second-order election effects? A refined second-order election model”, Comparative European Politics, Vol. 13 No. 6, pp. 636-655.

Schmitt, H. (2005), "The European parliament elections of June 2004: still second-order?", West European Politics, Vol. 28 No. 3, pp. 650-679.

Schmitt, H. and Teperoglou, E. (2015), "The 2014 European parliament elections in Southern Europe: second-order or critical elections?”, South European Society and Politics, Vol. 20 No. 3, pp. 287-309.

TVM (2019), "Upcoming MEP elections: 18,000 foreigners eligible to vote", available at:www.tvm.com. $\mathrm{mt} / \mathrm{en} /$ news/upcoming-mep-elections-18000-foreigners-eligible-to-vote/

Van der Brug, W. and De Vreese, C. (2016), "Introduction: consequences of European elections", in Van der Burg, W. and De Vreese, C.H. (Eds), (Un) Intended Consequencesof European Parliamentary Elections, Oxford University Press, Oxford, pp. 1-16. 
REPS

5,4

\section{Further reading}

De Sio, L., Franklin, M. and Russo, L. (eds.) (2019), The European Parliament Elections of 2019, Luiss University Press, Romania.

\section{About the authors}

Dr Jean Claude Cachia has been an academic with the Institute for European Studies since October 2015. He teaches modules in small states, European Security, research methods and political parties. He is currently the Outreach Coordinator of the Institute. Jean Claude obtained a Master of Arts in Diplomatic Studies in 2009 from the Mediterranean Academy of Diplomatic Studies and a Master of Arts in Research Methods in Politics and International Relations from the University of Sheffield in 2010. He was awarded a PhD in Politics from the University of Lincoln in 2014 with a doctoral dissertation based on the Impact of Europeanisation on Malta's Political Parties and Party Systems.

Fabrizio Ellul is a Visiting Lecturer at the University of Malta, teaching in the Department of International Relations. Since 2010 he has also been a Public Information Associate within UNHCR in Malta. In terms of his responsibilities with UNHCR, he established the Public Information Unit in Malta and is UNHCR Malta spokesperson.

Dr Mark Harwood is the Director of the Institute for European Studies and a Senior Lecturer in European Comparative Politics at the University of Malta. He has been an academic at the University of Malta since 2003, having previously worked for the European Commission. He won an EU-funded scholarship to study for the Masters in Contemporary European Studies at the University of Sussex in the UK from 1996 to 1997 and in 2009, he completed his Doctoral thesis in Public Management with a study on the Europeanisation of the Maltese Public Administration, published in 2014 by Ashgate as "Malta in the European Union". In addition to being Director of the Institute for European Studies, Dr Harwood sits on the University's Admissions Board. Mark Harwood is the corresponding author and can be contacted at:mark.harwood@um.edu.mt

Professor Carmen Sammut is Pro Rector for Student and Staff Affairs and Outreach at the University of Malta. She lectures in the Department of International Relations (Faculty of Arts) where she also served as Head of Department. She holds a $\mathrm{PhD}$ in Media and Communications from Goldsmiths College, University of London. She obtained her Masters (cum laude), a Post Graduate Certificate in Education (PGCE) and a BA Degree from the University of Malta. She currently teaches and writes about journalism, international communications, political communication and issues of culture in international affairs. At the University of Malta, she also teaches journalism within the Faculty of Media and Knowledge Sciences (MAKS). Carmen Sammut is a long-experienced broadcaster and regularly appears as an analyst discussing current events on Maltese media.

For instructions on how to order reprints of this article, please visit our website:

www.emeraldgrouppublishing.com/licensing/reprints.htm

Or contact us for further details: permissions@emeraldinsight.com 